\title{
A COMPARISON OF SURVIVAL AND GROWTH IN JUVENILE ASTACUS LEPTODACTYLUS (ESCH.) AND PACIFASTACUS LENIUSCULUS (DANA) UNDER CONTROLLED CONDITIONS
}

\author{
D. ULIKOWSKI (1), T. KRZYWOSZ (1), P. ŚMIETANA (2)
}

(1) The Stanislaw Sakowicz Inland Fisheries Institute in Olsztyn, Poland. E-mail: dgal@infish.com.pl

(2) Department of Ecology, University of Szczecin, Poland.

E-mail: leptosp@univ.szczecin.pl

Reçu le 28 juin 2005

Accepté le 18 janvier 2006

Received June 28, 2005

Accepted January 18, 2006

\begin{abstract}
The aim of this study was to compare survival and growth of juvenile narrow-clawed crayfish (Astacus leptodactylus) and signal crayfish (Pacifastacus leniusculus) fed only with experimental pellets ( $45 \%$ of proteins, $6 \%$ of fat, $20 \%$ crude fibre) under controlled conditions. The animals were reared in 12 (50 I) circular plastic tanks, the narrow-clawed crayfish set-ups being designated $A 1$ and $A 2$, the signal crayfish set-ups $P 1$ and $P 2$. The initial stocking densities for each species were 600 (A1, P1) and 1,200 (A2, P2) juveniles stage 2 per square metre for each set-up in three replicates. The experiment lasted 92 days under continuous photoperiod (L:D 24:0; 100 LUX) conditions at a temperature of $22.0 \pm 0.1^{\circ} \mathrm{C}$ and an oxygen saturation $>90 \%$. One shelter (plastic tube) was provided for 2 crayfish in each set-up.
\end{abstract}

The highest survival rate was obtained for signal crayfish from set-up P1 (47.5\%), the lowest for narrow-clawed crayfish from set-up A2 (22.8\%). Crayfish survival evidently depends on the stocking density: in set-ups $\mathrm{A} 1$ and $\mathrm{P} 1$ it was about $16 \%$ higher than in set-ups A2 and $P 2(P<0.05)$. Mortality was significantly higher $(P<0.05)$ in both species during the first 30 days of the experiment $(48-77 \%$ of the total mortality) than during the subsequent two months of the experiment $(<20 \%$ of the total mortality).

The final body size was the largest in narrow-clawed crayfish from set-up A1 (799 mg, $29.2 \mathrm{~mm}$ ) and the smallest in signal crayfish from set-up P2 (534 mg, $26.5 \mathrm{~mm}$ ). Specimens of narrow-clawed crayfish were larger than signal crayfish, and the specimens of both species in set-ups A1 and P1 were larger than those in set-ups A2 and P2. During the first 30 days of the experiment the specific growth rate (SGR) of both species in all set-ups was twice the value reported during the subsequent two months $(P<0.05)$. growth.

Key-words: Astacus leptodactylus, Pacifastacus leniusculus, juveniles, survival, 


\section{COMPARAISON DE LA SURVIE ET DE LA CROISSANCE DE JUVÉNILES CHEZ ASTACUS LEPTODACTYLUS (ESCH.) ET PACIFASTACUS LENIUSCULUS (DANA) DANS UN ENVIRONNEMENT CONTROLÉ}

\section{RÉSUMÉ}

Le but de cette étude était de comparer la survie et la croissance de juvéniles chez l'écrevisse à pattes grêles (Asatcus leptodactylus) et chez l'écrevisse signal (Pacifastacus leniusculus) maintenues dans un environnement contrôlé et nourris uniquement à l'aide de granulats expérimentaux ( $45 \%$ de protéines, $6 \%$ de graisses, $20 \%$ de fibres). Les animaux ont été élevés dans 12 bacs circulaires de 50 I. Les bacs contenant les écrevisses à pattes blanches ont été notés de $\mathrm{A} 1$ et $\mathrm{A} 2$ et ceux contenant les écrevisses signal $\mathrm{P} 1$ et P2. Chaque bac a été testé en triplicat. La densité initiale en juvéniles pour les deux espèces était de 600 individus au stade 2 pour $A 1$ et $P 1$ et de 1200 individus pour $A 2$ et P2 par mètre carré. L'expérience a été conduite pendant 92 jours sous une photopériode continue (jour: nuit 24:0; 100 LUX), avec une température de $22,0 \pm 0,1^{\circ} \mathrm{C}$ et une saturation en oxygène supérieure à $90 \%$. Dans chaque bac, un abri (tube en plastique) a été fourni pour deux écrevisses.

Le taux de survie le plus important a été obtenu pour le lot P1 (47,5\%) d'écrevisses signal et le moins important pour le lot A2 (22,8 \%) d'écrevisses à pattes grêles. La survie des écrevisses dépend évidemment de la densité de départ: dans les lots A1 et P1, la survie est supérieure de $16 \%$ par rapport à celle des lots $A 2$ et $P 2(P<0,05)$. La mortalité a été significativement plus importante $(P<0,05)$ pendant les 30 premiers jours de l'expérience (48-77\% de la mortalité totale) que pendant les deux derniers mois $(<20 \%$ de la mortalité totale).

Les écrevisses à pattes grêles du lot $\mathrm{A} 1$ ont présenté les tailles corporelles les plus grandes (799 mg;29,2 mm) alors que les plus petites ont été enregistrées dans le lot P2 (534 mg ; 26,5 mm). D'une façon générale, les écrevisses à pattes grêles étaient plus grandes que les écrevisses signal et les individus des lots A1 et P1 étaient aussi plus grands que ceux des lots A2 et P2. Pendant les 30 premiers jours de l'expérience, le taux de croissance spécifique (SGR) de chaque espèce (A1, $A 2, P 1, P 2)$ était plus important que celui mesuré dans les deux mois suivants $(P<0,05)$.

Mots-clés: Astacus leptodactylus, Pacifastacus leniusculus, juvéniles, survie, croissance.

\section{INTRODUCTION}

The range of distribution and the number of localities of native noble crayfish (Astacus astacus (L.)) and narrow-clawed crayfish (Astacus leptodactylus (Esch.)) in Poland have declined drastically in recent decades (KRZYWOSZ, 1994; BIAŁOKOZ et al., 1996). At present, the yields from natural waters are no greater than 2 tonnes per year (MASTYŃSKI and ANDRZEJEWSKI, 2001). This situation is due principally to the degradation and pollution of the natural environment, but several cases of crayfish plague (Aphanomyces astaci) and the expansion of spiny-cheek crayfish (Orconectes limosus (Raf.)) have also contributed. As a result, populations of noble crayfish and narrow-clawed crayfish are numerous only in SE Poland (KRZYWOSZ, 1994). Since the market value of native crayfish in Europe is higher than the one of imported species, it is more profitable to develop the farming of the former (HOLDICH, 1993), and many crayfish farmers in Europe have done precisely that (ACKEFORS, 1998). Crayfish farming also plays a significant role in the active protection of native species for restocking programmes (ACKEFORS and LINDQVIST, 1994; ACKEFORS, 1998; MASTYŃSKI and ANDRZEJEWSKI, 2001; SKURDAL and TAUGBØL, 2002; CARRAL et al., 2003; ŚMIETANA et. al., 2004). 
In Poland signal crayfish (Pacifastacus leniusculus) have the fastest rate of growth, reaching marketable sizes (10 cm TL) after 3 years of breeding, which is about one year earlier than our native species (KRZYWOSZ, 1994). The faster growth of the former species has also been reported from other European countries (ABRAHAMSSON, 1971; WESTMAN, 1973; CUKERZIS, 1989; ACKEFORS and LINDQVIST, 1994). But these reports are based on a comparison with crayfish growth under natural conditions, which is susceptible to a variety of environmental and climatic factors. Nevertheless, under controlled conditions it is possible to compare different crayfish species, which may enable these claims to be verified under the same breeding conditions. The results obtained by different authors (TCHERKASHINA, 1977; ULIKOWSKI and KRZYWOSZ, 2004a) show that the growth rate of narrow-clawed crayfish under optimal conditions is comparable to that of the signal crayfish.

The aim of this study was to compare, in a controlled experiment, survival and growth in juvenile narrow-clawed crayfish and signal crayfish fed with pellets ad libitum.

\section{MATERIAL AND METHODS}

The test animals were juveniles stage 2 (juveniles after the first moult) from both crayfish species. According JONSSON (1990) the signal crayfish juveniles may hatch about 2-4 weeks earlier than the native crayfish juveniles, may have a marked impact on growth during the first year after hatching. Similar observations were made in a comparison of narrow-clawed crayfish and spiny-cheek crayfish (SCHULZ and ŚMIETANA, 2001). Therefore, in order to obtain juveniles narrow-clawed crayfish at the same stage of development of signal crayfish, egg development was accelerated under controlled conditions. Narrow-clawed crayfish females carrying eggs were transferred from the breeding ponds ( $4^{\text {th }}$ May) to tanks in a re-circulating system. Water was heated from $10^{\circ}$ to $20^{\circ} \mathrm{C}$ over a period of 2 days. The signal crayfish females were taken from the ponds at a later date (20 $20^{\text {th }}$ May). The females of both species were kept in separate parts of the tanks $\left(120 \mathrm{~cm}^{2}\right)$ at a constant water temperature of $20^{\circ} \mathrm{C}$ until the $22^{\text {nd }}$ of May. The eggs were removed from the pleopods on the $22^{\text {nd }}$ of May and incubated further, each species separately, in Weiss apparatuses at a water temperature of $21^{\circ} \mathrm{C}$. The juveniles of both species hatched between $25^{\text {th }}$ and $27^{\text {th }}$ May, and the first moult took place between $4^{\text {th }}$ and $7^{\text {th }}$ June. The average total body length ( $T L-$ from the beginning of the rostrum to the end of the telson) and individual body weight of narrow-clawed crayfish and signal crayfish were similar, the respective measurements being $12.0 \pm 0.7 \mathrm{~mm}$ and $29 \pm 3 \mathrm{mg}$, and $11.0 \pm 0.5 \mathrm{~mm}$ and $28 \pm 3 \mathrm{mg}$.

The two species were reared separately in independent, identical water re-circulating systems, each of which consisted of $6(50 \mathrm{l})$ circular plastic tanks $\left(0.17 \mathrm{~m}^{2}\right)$ equipped with a thermoregulator and a biological water filter. Each tank contained shelters for crayfish (two crayfish per shelter) constituted from $18 \mathrm{~mm}$ diameter garden hose cut into $2-3 \mathrm{~cm}$ segments. There were two initial stocking densities - 600 and 1,200 specimens per square metre for each species in three replicates. The narrow-clawed crayfish setups were designated $A 1$ and $A 2$, the signal crayfish set-ups $P 1$ and $P 2$. The experiment lasted for 92 days under continuous photoperiod (L:D 24:0; 100 LUX) conditions. The crayfish were fed with experimental pellets ( $45 \%$ proteins, $6 \%$ fat, $20 \%$ crude fibre) provided ad libitum every 12 hours.

Water temperature and oxygen content were measured daily with an OxyGuard electronic device. Every two to three days water samples were collected for analysis: $\mathrm{pH}$ was determined with a PM 600 electronic device, ammonia nitrogen $\mathrm{N}^{-\mathrm{NH}_{4}}$ (Nessler method) and nitrite nitrogen $\mathrm{N}-\mathrm{NO}_{2}$ (sulphanil method) were determined colorimetrically on a Spekol 11 spectrophotometer. The average water temperature was $22.0 \pm 0.1^{\circ} \mathrm{C}$, and the oxygen content of the water was $>90 \%$. At pH 7.9-8.3, the ammonia nitrogen content did not exceed $0.1 \mathrm{mg} \mathrm{N}^{-\mathrm{NH}_{4}} \mathrm{l}$, and nitrite nitrogen was no greater than $0.04 \mathrm{mg} \mathrm{N}-\mathrm{NO}_{2} / \mathrm{l}$. 
After 30,61 and 92 days all the crayfish were caught and counted. The whole stock was weighed to the nearest $0.1 \mathrm{~g}$. The average individual crayfish body weight was calculated by dividing the stock biomass from each tank by the number of specimens it contained. Each of the tank stocks was photographed, and the length of 10-20 specimens from every tank was measured to the nearest $0.1 \mathrm{~mm}$ using the MultiScan computer program. At the end of the rearing period the same measurements were taken using 30 specimens from each setup. The initial measurements were similar but only 20 specimens were taken from each species. The specific growth rate (SGR) was calculated using the equation.

$$
S G R=\left(\operatorname{lnW}_{f}-\ln W_{i}\right) 100 / t
$$

Where:

$\operatorname{lnW}_{\mathrm{f}}$ is the natural logarithm of the final body weight,

$\operatorname{lnW}_{\mathrm{i}}$ is the natural logarithm of the initial body weight, and

$t$ is the time (days) between $\ln W_{f}$ and $\ln W_{i}$.

The growth results, SGR, and mortality were analysed statistically using the Statistica 5.1 computer program. One-way analysis of variance (ANOVA) was applied, and the post-hoc averages were compared using Tukey's test at a significance level of $\mathrm{P}<0.05$.

\section{RESULTS}

After 92 days of rearing the survival rate was highest in the signal crayfish from setup P1 (47.5\%) and lowest in the narrow-clawed crayfish from set-up A2 (22.8\%). In all the setups the final survival of the signal crayfish was higher than the one of the narrowclawed crayfish (Table I), but these differences were not significant $(P>0.05)$. Crayfish survival was clearly dependent on the stocking density: in set-ups $A 1$ and $P 1$ survival was about $16 \%$ higher than in set-ups $A 2$ and $P 2(P<0.05)$.

Mortality in both species was significantly high during the first 30 days of the experiment (48-77\% of the total mortality) but significantly lower during the next two months (Figure 1A). The temporal mortality pattern was different in both species, although the final mortality depended only on the initial stocking density $(P<0.05)$ and did not vary between the two species.

The final body size was the largest in the narrow-clawed crayfish from set-up A1 (799 mg, $29.2 \mathrm{~mm}$ ), and the smallest in the signal crayfish from set-up P2 (534 mg, $26.5 \mathrm{~mm}$ ). Specimens of narrow-clawed crayfish were larger than signal crayfish, and the specimens of both species in set-ups A1 and P1 were larger than in set-ups A2 and P2. Again, the differences were not significant $(P>0.05)$ owing to the high variation in juvenile size within each set-up (Table I).

In the first 30 days of the experiment the specific growth rate (SGR) in all set-ups was twice as high as during the following two months $(P<0.05)$. During the first month of the experiment narrow-clawed crayfish grew faster $(P<0.05)$ than signal crayfish. During the second, the growth rate was similar, and during the third signal crayfish grew faster $(P<0.05)$ than narrow-clawed crayfish (Figure 1B).

Even though the initial stocking densities in set-ups A1 and P1 were half the size of $\mathrm{A} 2$ and $\mathrm{P} 2$, the biomasses in the two groups of set-ups gradually converged, so that the final total biomass in all set-ups was similar (Figure 1C). The biomass of narrow-clawed crayfish increased during the third month of rearing only in the set-up with the lower initial stocking density. In both set-ups the final biomasses reached a similar maximum 


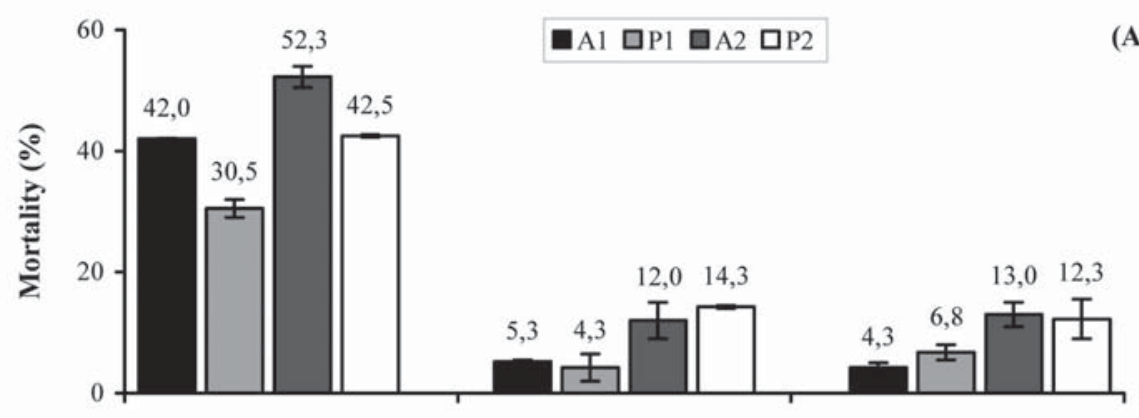

(A)
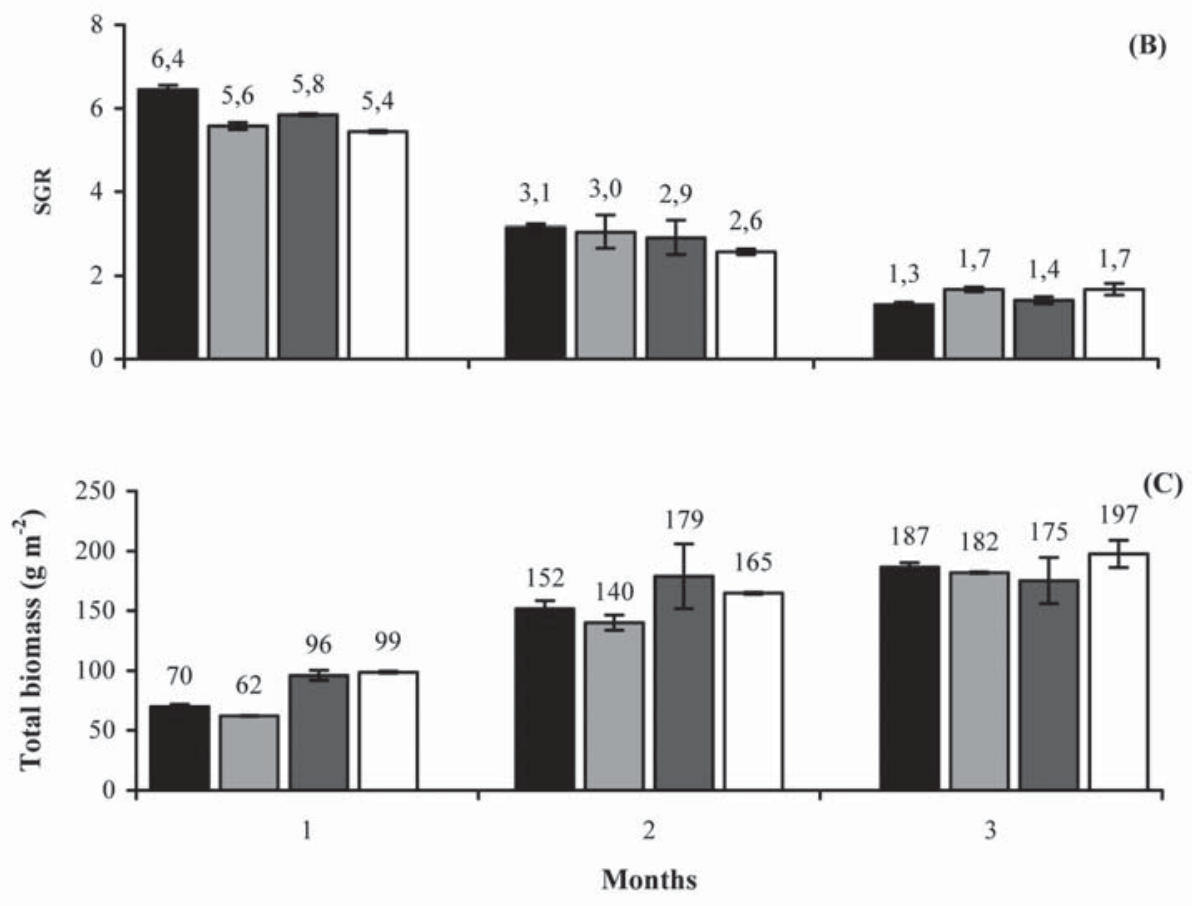

Figure 1

Mortality (A), SGR (B), and total biomass (C) of juveniles narrow-clawed crayfish and signal crayfish reared during three months after hatching under controlled conditions.

A1 - narrow-clawed crayfish with initial density 600 individuals per square meter.

P1 - signal crayfish with initial density 600 individuals per square meter.

A2 - narrow-clawed crayfish with initial density 1,200 individuals per square meter.

P2 - signal crayfish with initial density 1,200 individuals per square meter.

Figure 1

Mortalité (A), taux de croissance spécifique (SGR) (B) et biomasse totale (C) des juvéniles d'écrevisses à pattes grêles et d'écrevisses signal élevées pendant trois mois dans un environnement contrôlé après l'éclosion.

A1 - écrevisse à pattes grêles avec une densité initiale de 600 individus par mètre carré.

$P 1$ - écrevisse signal avec une densité initiale de 600 individus par mètre carré.

A2 - écrevisse à pattes grêles avec une densité initiale de 1200 individus par mètre carré.

P2 - écrevisse signal avec une densité initiale de 1200 individus par mètre carré. 
level of about $185 \mathrm{~g}$ per square metre. Nevertheless, the biomass of the signal crayfish also increased in the third month of the rearing experiment, finally reaching a maximum of $197 \mathrm{~g}$ per square metre. This similar final biomass was due to the higher mortality of crayfish in set-ups A2 and P2 than in set-ups A1 and P1, due to the higher initial stocking densities in the former set-ups. At higher stocking densities more individuals lost chelae and walking legs. More signal crayfish than narrow-clawed crayfish sustained this kind of mutilation.

\section{DISCUSSION}

The results obtained from our experiment show a similar growth rate in both species during the first three months after hatching. Similar observations were made with older individuals of both species after six months of rearing in our previous investigations (ULIKOWSKI and KRZYWOSZ, 2004a), where the SGR was 0.71 in narrow-clawed crayfish and 0.74 in signal crayfish. The different growth rates of these species in breeding ponds and natural waters may be due to a variety of environmental factors and interspecific differences. According to LOZAN (2000), 33\% of the activity of the signal crayfish takes place during daylight, while this figure is only $16 \%$ in the narrow-clawed crayfish. In natural environments, therefore, signal crayfish are likely to find food more effectively than native crayfish. Obviously, then, narrow-clawed crayfish are more active at night. They are also much more mobile, capable of covering a distance of 1587 metres in 24 hours, whereas the signal crayfish moves only 190 metres in the same time (LOZAN, 2000).

After 92 days the two experimental species achieved relatively good growth: mean body lengths varied from 27.1 to $29.2 \mathrm{~mm}$ TL. These results suggest that the conditions for the crayfish during the whole experiment had been optimal. CELADA et al. (1993), for example, reported that the mean carapace length $(C L=\sim 50 \%$ of $T L)$ varied from 7.2 to $7.5 \mathrm{~mm}$ after 110 days of breeding in plastic basins, even though the juvenile signal crayfish these authors examined were kept at much smaller initial densities (50 animals per square metre) and their final sizes were $\sim 50 \%$ smaller than in our experiment. The same applies to juvenile survival: CELADA et al. (1993) reported a diet-dependent survival from $5.3 \%$ to $38.7 \%$ after 110 days of breeding, while in our experiment the survival of signal crayfish ranged from $31.0 \%$ to $47.5 \%$.

In our study, mortality was highest during the first month $(48-77 \%$ of the total mortality) in both species, but fell considerably during the ensuing two months. Similarly, SÁEZ-ROYUELA et al. (1995) reported the highest mortality in signal crayfish juveniles during the first 40-60 days following female departure. NYSTRÖM (1994) listed the following main factors affecting the survival of signal crayfish juveniles: stocking density, number of shelters, light intensity, accessibility and quantity of food. The results of our investigations revealed the negative effect of higher stocking densities on growth and survival in both species. Different authors have described similar effects (ACKEFORS et al., 1989; GYDEMO and WESTIN, 1989; ACKEFORS and LINDQVIST, 1994; MACKEVICIENE et al., 1996). High stocking densities intensify mutual aggression and cannibalism, resulting in increased mortality and in a larger number of individuals with lost legs. A similar effect was observed after four weeks of rearing of narrow-clawed crayfish juveniles (ULIKOWSKI and KRZYWOSZ, 2004b), where survival was $70 \%, 58 \%$ and $47.8 \%$ from respective initial stocking densities of 300,600 and 1,200 animals per square metre. The results of our experiment confirmed the impact of initial density on crayfish survival during the first months of breeding. CELADA et al. (1993) observed the same effect in signal crayfish. These authors succeeded in achieving a high survival rate of $50-70 \%$ in signal crayfish juveniles when they were kept individually in cylindrical compartments for 80 days of the breeding period under laboratory conditions. In breeding ponds, given favourable conditions, the chances of surviving the first year of life are high (45-90\%) for both signal crayfish (KRZYWOSZ, 1994; KOZAK et al., 1998) and narrow-clawed crayfish 
(TCHERKASHINA, 1977). Most authors therefore recommend rearing crayfish in small ponds (CUKERZIS, 1989; HOLDICH, 1993, 2002; ACKEFORS and LINDQVIST, 1994; ACKEFORS, 1998) with initial stocking densities of juveniles stage 2 of no more than 100 individuals per square metre.

Although the stocking densities in our investigations were higher, the final results of growth and survival in narrow-clawed and signal crayfish were similar to those obtained by other authors (CELADA et al., 1989; ACKEFORS and LINDQVIST, 1994; SÁEZ-ROYUELA et al., 1995). It seems that laboratory conditions (shelter density) reduce the considerable stress experienced by newly moulted crayfish as they constantly try to avoid competition with the other crayfish present in the basins (TAUGBØL 1989). Our results show that it is possible to breed crayfish at high initial densities and to obtain relatively high survival rates, whereas under natural conditions, usually no more than $10 \%$ of the same species survive the first year of life (TCHERKASHINA, 1977; ULIKOWSKI, 1996). This is the effect of very much greater number of biotic and abiotic stressors under natural conditions than under breeding conditions (LEWIS, 2002). To summarise our results on survival: both crayfish species can be bred at relatively high initial densities, although an initial density of 600 individuals per square metre appears to promise better results than 1,200 individuals per square metre.

The lack of significant differences in the final biomass in all setups shows that the rate of growth of the signal crayfish, reported as being a fast-growing species, is similar to the one of the native narrow-clawed crayfish under the same laboratory conditions. The same applies to SGR and survival. The only differences, displayed in the mortality pattern, may have been induced by behavioural differences between the species. During the experiment the signal crayfish were more aggressive than the narrow-clawed crayfish, and most individuals of the former species lost chelae or walking legs. Many authors showed that signal crayfish are more aggressive than our native species (SÖDERBÄCK, 1991; LOZAN, 2000; LEWIS, 2002). It has been observed that when signal crayfish are bred together with narrow-clawed crayfish, they exhibit greater aggression towards their conspecifics, while at the same time avoiding clashes with narrow-clawed crayfish (ULIKOWSKI AND KRZYWOSZ, 2004a).

\section{ACKNOWLEDGEMENT}

This investigation was financially supported by the Polish Committee of Sciences project No. 3. PO 4 F 072 23. Special thanks are due to Ralf Schulz for valuable help and an anonymous reviewer for important remarks and advices.

\section{REFERENCES}

ABRAHAMSSON S., 1971. Density, growth and reproduction in populations of Astacus astacus and Pacifastacus leniusculus in an isolated pond. Oikos, 22, 373-380.

ACKEFORS H., 1998. The culture and capture crayfish fisheries in Europe. Word Aquaculture, 29(2), 18-24, 64-67.

ACKEFORS H., GYDEMO R., WESTIN L., 1989. Growth and survival of juvenile crayfish, Astacus astacus, in relation to food and density. In: Biotechnology in progress. Eds: N. De PAUW, E. JASPERS, H. ACKEFORS, N. WILKINS. European Aquaculture Society, Bredene, Belgium: 365-373.

ACKEFORS H., LINDQVIST O.V., 1994. Cultivation of freshwater crayfishes in Europe. In: Freshwater crayfish aquaculture in North America, Europe and Australia, Families Astacidae, Cambaridae and Parastacidae. Ed.: J.V. HUNER. Howorth, Binghamton, NY: 157-216. 
BIAŁOKOZ W., CHYBOWSKI L., KRZYWOSZ T., 1996. Endangered crayfish species in Suwalki voyevodeship. Zoologia Poloniae, 41 (Suppl.), 87-91.

CARRAL J.M., SAEZ-ROYUELA M., CELADA J.D., PEREZ J.R., MELENDRE P.M., AGUILERA A., 2003. Advantages of artificial reproduction techniques for whiteclawed crayfish (Austropotamobius pallipes Lereboullet 1858). Bull. Fr. Pêche Piscic., 370-371, 181-184.

CELADA J.D., CARRAL J.M., GAUDIOSO V.R., TEMINO C., FERNANDEZ R., 1989. Response of juvenile freshwater crayfish (Pacifastacus leniusculus Dana) to several fresh and artificially compounded diets. Aquaculture, 76, 67-78.

CELADA J.D., CARRAL J.M., GAUDIOSO V.R., FERNANDEZ R., 1993. Survival and growth of juvenile freshwater crayfish Pacifastacus leniusculus Dana fed two raw diets and two commercial formulated feeds. Journal of the World Aquaculture Society, 24(1), 108-111.

CUKERZIS J., 1989. Rečnye raki. Mokslas, Wilno: 136 pp. (in Russian).

GYDEMO R., WESTIN L., 1989. Growth and survival of juvenile crayfish, Astacus astacus L., in optimized water conditions. In: Biotechnology in progress. Eds: N. DE PAUW, E. JASPERS, H. ACKEFORS, N. WILKINS. European Aquaculture Society, Bredene, Belgium, 383-392.

HOLDICH D.M., 1993. A review of astaciculture: Freshwater crayfish farming. Aquatic Living Resources, 6(4), 307-317.

HOLDICH D.M., 2002. Biology of freshwater crayfish. Blackwell Science Ltd, Oxford, $674 \mathrm{pp}$.

JONSSON A., 1990. Life history differences between crayfish Astacus astacus and Pacifastacus leniusculus in embryonic and juvenile development, laboratory experiences. Freshwater Crayfish, 8, 170-178.

KOZAK P., KOURIL J., HAMACKOVA J., 1998. Growth rates of two groups of juvenile signal crayfish (Pacifastacus leniusculus) originating from females reared in pond and warm water. Bulletin VURH Vodnany, 3, 99-102 (in Czech with English Abstract).

KRZYWOSZ T., 1994. The introduction of the crayfish Pacifastacus leniusculus Dana, into polish waters. Roczniki Naukowe PZW, 7, 81-93 (in Polish with English Abstract).

LEWIS S.D., 2002. Pacifastacus. In: Biology of Freshwater Crayfish. Ed.: D.M. Holdich. Blackwell Science Ltd, Oxford, 511-540.

LOZAN J.L., 2000. On the threat to the European crayfish: A contribution with the study of the activity behavior of four crayfish species (Decapoda: Astacidae). Limnologica, 30(2), 156-166.

MACKEVICIENE G., MICKENIENE L., BURBA A., PECIUKENAS A., KOREIVA C., LAPIENE A., JONYNIENE A., VISELGA A., 1996. Acceleration of natural reproduction of the crayfish Astacus astacus and rearing of juveniles up to the stage of summerlings. In: Fishery and Aquaculture in Lithuania II. Ed.: E. MILERIENE. The Lithuanian Society of Hydrobiologist, Vilnius, 353-376 (in Lithuanian and English Summary).

MASTYŃSKI J., ANDRZEJEWSKI W., 2001. Extinction of the noble crayfish Astacus astacus (L.) in Poland. Bulletin VURH Vodnany, 37, 133-135 (in Czech with English Abstract).

NYSTRÖM P., 1994. Survival of juvenile signal crayfish (Pacifastacus leniusculus) in relation to light intensity and density. Nordic Journal Freshwater Research, 69, 162-166. 
SÁEZ-ROYUELA M., CARRAL J.M., CELADA J.D., MUNOZ C., 1995. Effects of management on survival and growth of stage 2 juvenile freshwater signal crayfish (Pacifastacus leniusculus Dana) under laboratory conditions. Aquaculture, 133(2), 123-133.

SCHULZ R., ŚMIETANA P., 2001. Occurrence of native and introduced crayfish in Northeastern Germany and Northwestern Poland. Bull. Fr. Pêche Piscic., 361, 629641.

SKURDAL J., TAUGBØL T., 2002. Astacus. In: Biology of Freshwater Crayfish. Ed.: D.M. HOLDICH. Blackwell Science Ltd, Oxford, 467-510.

SÖDERBÄCK B., 1991. Interspecific dominance relationship and aggressive interactions in freshwater crayfishes Astacus astacus (L.) and Pacifastacus leniusculus (Dana). Canadian Journal of Zoology, 69, 1321-1325.

ŚMIETANA P., KRZYWOSZ T., STRUŻYŃSKI W., 2004. Review of National Restocking Program "Active Protection of Native Crayfish in Poland" 1999-2001. Bull. Fr. Pêche Piscic., 372-373, 289-301.

TAUGBØL T., 1989. Crayfish culture in Norway. In: Crayfish culture in Europe. Directorate for Nature Management. Eds: J. SKURDAL, K. WESTMAN and P.I. BERGAN. Trondheim, Norway, 101-117.

TCHERKASHINA N.Ya., 1977. Survival, growth, and feeding dynamics of juvenile crayfish (Astacus leptodactylus cubanicus) in ponds and the river Don. Freshwater Crayfish, 3, 95-100.

ULIKOWSKI D., 1996. Podchów raków sygnałowych (Pacifastacus leniusculus Dana) w warunkach kontrolowanych. Komunikaty Rybackie, 1, 28-29 (in Polish).

ULIKOWSKI D., KRZYWOSZ T., 2004a. Wpływ konkurencji międzygatunkowej na wyniki chowu raków błotnych (Astacus leptodactylus Esch.) i sygnałowych (Pacifastacus leniusculus Dana). In: Rozród, podchów, profilaktyka ryb jesiotrowatych i innych gatunków. Eds.: Z. ZAKĘŚ, R. KOLMAN, K. DEMSKA-ZAKĘŚ, T. KRZYWOSZ. IRS Olsztyn, 169-176 (in Polish).

ULIKOWSKI D., KRZYWOSZ T., 2004b. The impact of photoperiod and stocking density on the growth and survival of narrow-clawed crayfish (Astacus leptodactylus Esch.) larvae. Archives of Polish Fisheries, 12(1), 81-86.

WESTMAN K., 1973. Cultivation of the American crayfish, Pacifastacus leniusculus. Freshwater Crayfish, 1, 211-220. 
